Article

\title{
Novel Aluminum Oxide-Impregnated Carbon Nanotube Membrane for the Removal of Cadmium from Aqueous Solution
}

\author{
Ihsanullah ${ }^{1}$, Faheemuddin Patel ${ }^{2}$ (D), Majeda Khraisheh ${ }^{3}$ (D), Muataz Ali Atieh ${ }^{4, *}$ \\ and Tahar Laoui ${ }^{2, *}$ \\ 1 Center for Environment and Water (CEW), Research Institute, King Fahd University of Petroleum \\ and Minerals, Dhahran 31261, Saudi Arabia; engr.ihsan.dir@gmail.com \\ 2 Department of Mechanical Engineering, King Fahd University of Petroleum \& Minerals, \\ Dhahran 31261, Saudi Arabia; faheemmp@kfupm.edu.sa \\ 3 Department of Chemical Engineering, Qatar University, Doha 2713, Qatar; m.khraisheh@qu.edu.qa \\ 4 College of Science and Engineering, Hamad Bin Khalifa University, Qatar Foundation, Doha 5825, Qatar \\ * Correspondence: tlaoui@kfupm.edu.sa (T.L.); mhussien@hbku.edu.qa (M.A.A.)
}

Received: 13 August 2017; Accepted: 12 September 2017; Published: 28 September 2017

\begin{abstract}
An aluminum oxide-impregnated carbon nanotube $\left(\mathrm{CNT}-\mathrm{Al}_{2} \mathrm{O}_{3}\right)$ membrane was developed via a novel approach and used in the removal of toxic metal cadmium ions, $\mathrm{Cd}(\mathrm{II})$. The membrane did not require any binder to hold the carbon nanotubes (CNTs) together. Instead, the $\mathrm{Al}_{2} \mathrm{O}_{3}$ particles impregnated on the surface of the CNTs were sintered together during heating at $1400{ }^{\circ} \mathrm{C}$. Impregnated CNTs were characterized using XRD, while the $\mathrm{CNT}-\mathrm{Al}_{2} \mathrm{O}_{3}$ membrane was characterized using scanning electron microscopy (SEM). Water flux, contact angle, and porosity measurements were performed on the membrane prior to the $\mathrm{Cd}(\mathrm{II})$ ion removal experiment, which was conducted in a specially devised continuous filtration system. The results demonstrated the extreme hydrophilic behavior of the developed membrane, which yielded a high water flux through the membrane. The filtration system removed $84 \%$ of the $\mathrm{Cd}(\mathrm{II})$ ions at $\mathrm{pH} 7$ using CNT membrane with $10 \% \mathrm{Al}_{2} \mathrm{O}_{3}$ loading. A maximum adsorption capacity of $54 \mathrm{mg} / \mathrm{g}$ was predicted by the Langmuir isotherm model for the CNT membrane with $10 \% \mathrm{Al}_{2} \mathrm{O}_{3}$ loading. This high adsorption capacity indicated that adsorption was the main mechanism involved in the removal of $\mathrm{Cd}$ (II) ions.
\end{abstract}

Keywords: membrane; carbon nanotubes; aluminum oxide; cadmium; toxic metal

\section{Introduction}

Cadmium is a well-known highly toxic metal found in drinking water, and is associated with major negative health impacts. The World Health Organization guidelines suggest an allowable limit of cadmium ions, $\mathrm{Cd}(\mathrm{II})$, in water of $0.003 \mathrm{mg} / \mathrm{L}$ [1]. Cadmium primarily accumulates in the kidneys, and has a relatively long biological half-life of 10 to 35 years in humans [2]. A potential source of cadmium contamination in drinking water is industrial wastewater, such as that produced by the manufacturing processes for smelting, pesticides, fertilizers, dyes, pigments, refining, and textile operations. Cadmium contamination of drinking water might also be caused by the presence of Cd(II) ions as an impurity in the zinc of galvanized pipes and certain metal fittings [3,4].

Various toxic metal decontamination techniques (such as adsorption, precipitation, reduction, ion exchange, precipitation, solvent extraction, electrolytic recovery, and chemical oxidation) have been applied for the removal of toxic metals from water [3,5]. However, the majority of these methods have limited applications due to economical or technical constraints. Water treatment by adsorption offers the most practical and economical treatment alternative. Numerous adsorbents have been used 
in the removal of metal ions from water, including activated carbon, fly ash, biomaterials, zeolite, recycled alum sludge, algal biomass, peanut hulls, resins, kaolinite, manganese oxides, and carbon nanotubes [6]. However, the majority of the adsorption techniques are batch-level processes and are unable to process large amounts of contaminated water. Carbon nanotube-based novel membranes are a promising candidate for toxic metal removal.

CNTs have attracted considerable attention in recent years as a novel adsorbent for the adsorption of numerous pollutants from water, including toxic metal ions [3,6] and organic chemicals [7-10]. CNTs have also emerged as an ideal candidate for the synthesis of unique membranes with excellent properties for applications in water treatment [11-13]. The friction-less and smooth graphitic walls of CNTs are considered ideal channels for enhanced molecule transport [13-15]. CNTs can be used either as fillers to improve the mechanical, electrical, and thermal properties of various polymeric membranes or as a direct filter [16-19].

Different types of CNT-based membranes have been reported in the published literature. The most common categories include mixed-matrix membranes [16-19], vertically aligned CNT membranes [20,21], bucky paper membranes [22-24], and template-assisted open-ended CNT membranes $[25,26]$.

In this work, a novel approach for the synthesis of CNT membranes is presented using a powder metallurgy technique. To avoid heating at extremely high temperatures (approximately $3000{ }^{\circ} \mathrm{C}$ ) to bond the CNTs together, aluminum oxide $\left(\mathrm{Al}_{2} \mathrm{O}_{3}\right)$ particles are impregnated onto the surface of CNTs and used to bond the 3D CNT network together during a sintering process performed at only $1400{ }^{\circ} \mathrm{C}$ to produce the CNT membrane. Moreover, surface impregnation of CNTs has been reported to yield an enhanced surface area and better adsorption capacity for the removal of different contaminants from water [27]. CNTs were impregnated via a wet chemistry technique with different loadings of aluminum oxide. Impregnated CNTs were characterized using XRD, and the developed membranes were analyzed to measure the contact angle, porosity, and water flux. The potential of the membrane for cadmium removal was investigated using a continuous flow system. The effect of $\mathrm{pH}$, aluminum oxide loading onto the CNTs, initial cadmium concentration of the solution, and time, on the removal efficiency of $\mathrm{Cd}(\mathrm{II})$ ions, was investigated.

\section{Materials and Methods}

\subsection{Materials}

CNTs with a purity $>95 \%$ were acquired from Chengdu Organic Chemicals Co. Ltd., China (Chengdu, China) with an outside diameter of 10-20 nm and a length of 1-10 $\mu$. Aluminum isopropoxide $\left[\mathrm{C}_{9} \mathrm{H}_{21} \mathrm{O}_{3} \mathrm{Al}\right.$ ] (purity $\geq 98 \%$, Sigma Aldrich, Saint Louis, MO, USA) was used as a precursor for aluminum oxide.

\subsection{Impregnated Aluminum Oxide-Carbon Nanotubes}

The surfaces of the CNTs were impregnated with $\mathrm{Al}_{2} \mathrm{O}_{3}$ nanoparticles via the wet impregnation method [28,29]. The loading content of $\mathrm{Al}_{2} \mathrm{O}_{3}$ ranged from 1 to $20 \%$ (by weight, wt $\%$ ). In this method, to prepare $10 \% \mathrm{Al}_{2} \mathrm{O}_{3}$ loading, $7.5 \mathrm{~g}$ of aluminum isopropoxide $\left[\mathrm{C}_{9} \mathrm{H}_{21} \mathrm{O}_{3} \mathrm{Al}\right]$ was dissolved in $500 \mathrm{~mL}$ of ethanol (98\% purity). Nine grams of CNTs were dispersed in a separate $500 \mathrm{~mL}$ of ethanol. These mixtures were separately ultrasonicated for $1 \mathrm{~h}$ and subsequently mixed together. The mixture was further ultrasonicated for $1 \mathrm{~h}$ at ambient temperature, to ensure a homogeneous dispersion of the CNTs. To remove the ethanol solvent, the mixture was stored in an oven overnight at the required temperature. The residue was calcinated in a tube furnace under argon at $350{ }^{\circ} \mathrm{C}$ for $4 \mathrm{~h}$. This process results in the attachment of $\mathrm{Al}_{2} \mathrm{O}_{3}$ particles onto the surface of CNTs. A similar procedure was used to prepare CNTs with various $\mathrm{Al}_{2} \mathrm{O}_{3}$ loading percentages (between $1 \%$ and $20 \%$ ). 


\subsection{Membrane Preparation}

The $\mathrm{Al}_{2} \mathrm{O}_{3}$-impregnated CNTs, prepared as described in Section 2.1, were uniaxially pressed at $200 \mathrm{MPa}$ compaction pressure using a circular metallic die in a hydraulic bench-type press (4387 N.E.L, Carver, Inc., Wabash, IN, USA). This process resulted in a compact disc $(27 \mathrm{~mm}$ in diameter and $3 \mathrm{~mm}$ thick) containing $1 \%, 10 \%$, and $20 \% \mathrm{Al}_{2} \mathrm{O}_{3}$. The compacted discs were sintered at $1400{ }^{\circ} \mathrm{C}$ for $5 \mathrm{~h}$ under argon (300-400 mL/min) in a tube furnace (GSL-1700X, MTI Corporation, Richmond, CA, USA). A schematic representation of the synthesis route is shown in Figure 1.

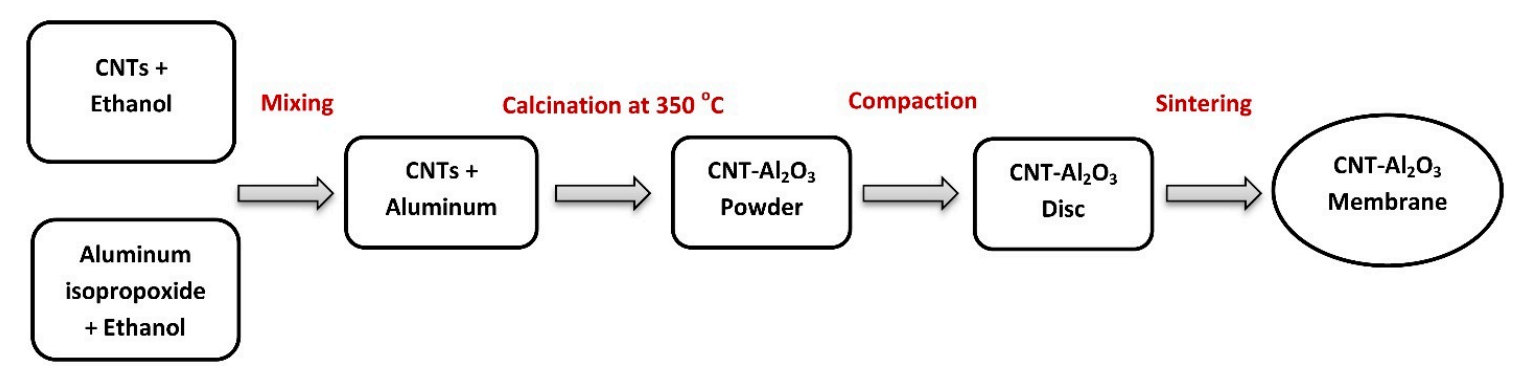

Figure 1. Flowchart for the synthesis of aluminum oxide-impregnated carbon nanotube $\left(\mathrm{CNTs}-\mathrm{Al}_{2} \mathrm{O}_{3}\right)$ membrane.

\subsection{Characterization Analysis of Raw and Impregnated CNTs and Membranes}

\subsubsection{SEM Analysis}

SEM studies of the membranes were performed using field emission scanning electron microscopy (TESCAN MIRA 3 FEG-SEM, TESCAN, Brno-Kohoutovic, Czech Republic).

\subsubsection{X-ray Diffraction (XRD)}

The XRD patterns for raw and impregnated CNTs were measured at a rate of $1.0^{\circ} / \mathrm{min}$ in the range of $10^{\circ}-80^{\circ}(2 \alpha)$ using an X-ray diffractometer equipped with a $\mathrm{Cu} \mathrm{K} \alpha$ radiation source $(40 \mathrm{kV}, 20 \mathrm{~mA})$.

\subsubsection{Porosity Measurement}

The dry-wet method [16] was used to determine the porosity of the membranes using Equation (1):

$$
\text { Porosity }=\frac{W_{2}-W_{1}}{\rho \cdot V} \times 100 \%
$$

where $W_{1}(\mathrm{~g})$ and $W_{2}(\mathrm{~g})$ are the weights of the dry and wet membranes, respectively; $V\left(\mathrm{~cm}^{3}\right)$ is the volume of the membrane; and $\rho\left(\mathrm{g} / \mathrm{cm}^{3}\right)$ is the density of distilled water at ambient temperature. The membrane was immersed in distilled water for $24 \mathrm{~h}$, and its wet weight was measured. The membrane was subsequently dried in an oven at $90{ }^{\circ} \mathrm{C}$ for $24 \mathrm{~h}$, and the dry weight of the membrane was measured. The experiment was performed in triplicate, and the data are presented as the mean value of all experiments.

\subsubsection{Contact Angle Measurement}

A contact angle analyzer (model DM-301, KYOWA, Niiza, Japan) was used to measure the contact angle of the membrane surface and hence the hydrophobicity/hydrophilicity of the membrane.

\subsubsection{Zeta Potential Measurement}

The zeta potential for a suspension of $0.5 \mathrm{~g} / \mathrm{L} \mathrm{CNTs}-\mathrm{Al}_{2} \mathrm{O}_{3}$ in distilled water was determined using a Malvern ZEN2600 Zetasizer Nano Z (Malvern, Worcestershire, UK) at pH 2.0-10 (adjusted with $0.1 \mathrm{M} \mathrm{NaOH}$ or $\mathrm{HNO}_{3}$ ). 


\subsection{Continuous Filtration System}

The main components of the continuous filtration system used in this study (presented in Figure 2) were a membrane cell with an effective surface area of $5.7 \mathrm{~cm}^{2}$, a $10 \mathrm{~L}$ feed tank, and the required pressure pump and flow meter. The membrane was placed in a circular housing with a mesh underneath it as a support structure to maintain the stability of the membrane during the flow experiments. The pure water flux analysis was performed before the $\mathrm{Cd}(\mathrm{II})$ remediation studies were performed. The pure water flux was measured using Equation (2) $[16,28,29]$ :

$$
J=V /(A \cdot t)
$$

where $J\left(\mathrm{~L} \cdot \mathrm{m}^{-2} \cdot \mathrm{h}^{-1}\right)$ is the water flux, $t(\mathrm{~h})$ is the time required for permeate water to pass through the membrane, and $V(\mathrm{~L})$ is the volume of permeate water.

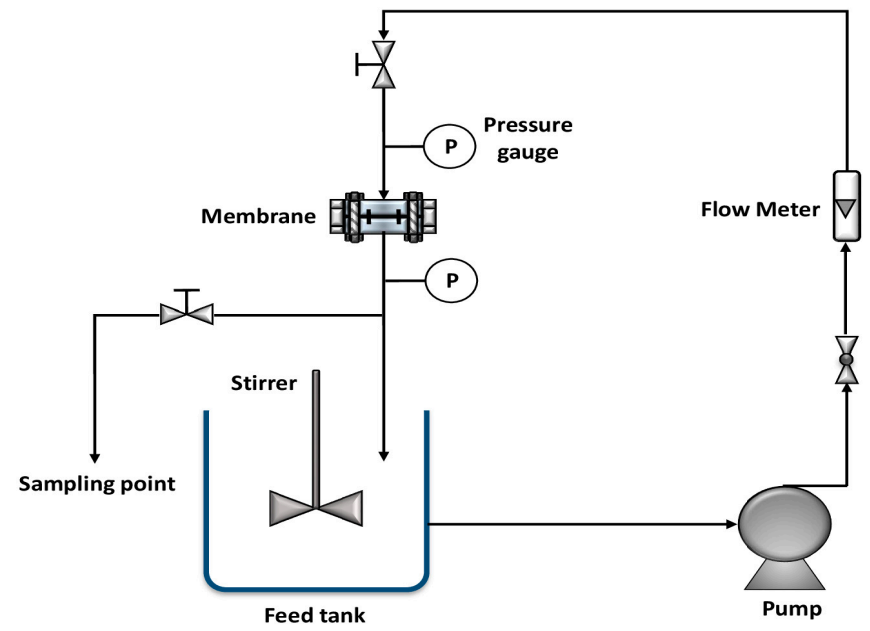

Figure 2. Schematic diagram of the flow loop system.

For cadmium removal, the experimental runs began with the circulation of a $1 \mathrm{ppm}$ solution of $\mathrm{Cd}(\mathrm{II})$ from the feed tank through the system. An initial volume of approximately $10 \mathrm{~L}$ was added to the feed tank, and the $\mathrm{pH}$ was adjusted using $1 \mathrm{M} \mathrm{NaOH}$ or $1 \mathrm{M} \mathrm{HNO}_{3}$, as required. The pressure and flow rate were adjusted to the desired values. Permeate (purified water) passing through the membrane was collected from the sample collection point (shown in Figure 2) at different time intervals using sample bottles with volumes of approximately $20 \mathrm{~mL}$. The effects of the initial concentration, time, $\mathrm{pH}$, and membrane $\mathrm{Al}_{2} \mathrm{O}_{3}$ loading on cadmium removal were studied.

Table 1 shows the experimental conditions for $\mathrm{Cd}(\mathrm{II})$ removal using different $\mathrm{CNT}-\mathrm{Al}_{2} \mathrm{O}_{3}$ membranes. First, a CNT membrane with $10 \% \mathrm{Al}_{2} \mathrm{O}_{3}$ loading was used to determine the optimum $\mathrm{pH}$ for the maximum removal of $\mathrm{Cd}(\mathrm{II})$. The transmembrane pressure difference and concentration of $\mathrm{Cd}$ (II) were held constant during these experiments. The optimum $\mathrm{pH}(\mathrm{pH}=7)$ was held constant during the remainder of the experiments, and the effects of $\mathrm{Al}_{2} \mathrm{O}_{3}$ loading and the initial $\mathrm{Cd}(\mathrm{II})$ concentration in the solution (water) on the removal efficiency of $\mathrm{Cd}(\mathrm{II})$ ions were determined.

Table 1. Experimental matrix of parameters used in the removal of cadmium with the developed membranes.

\begin{tabular}{ccccc}
\hline $\begin{array}{c}\text { Experimental } \\
\text { Set }\end{array}$ & $\begin{array}{c}\mathbf{A l}_{\mathbf{2}} \mathbf{O}_{3} \text { Loading (wt \%) in } \\
\text { the Membrane }\end{array}$ & $\begin{array}{c}\text { Transmembrane Pressure } \\
\text { Difference (psi) }\end{array}$ & $\begin{array}{c}\text { pH of the } \\
\text { Solution }\end{array}$ & $\begin{array}{c}\text { Initial Concentration of } \\
\text { Cd(II) (ppm) }\end{array}$ \\
\hline 1 & $\mathrm{CNT}-10 \% \mathrm{Al}_{2} \mathrm{O}$ & 15 & $3,5,7,8,10$ & 1 \\
2 & $\mathrm{CNT}-1 \% \mathrm{Al}_{2} \mathrm{O}_{3}$ & 15 & 7 & $0.5,1,5,10$ \\
3 & $\mathrm{CNT}-10 \% \mathrm{Al}_{2} \mathrm{O}_{3}$ & 15 & 7 & $0.5,1,5,10$ \\
4 & $\mathrm{CNT}-20 \% \mathrm{Al}_{2} \mathrm{O}_{3}$ & 15 & 7 & $0.5,1,5,10$ \\
\hline
\end{tabular}




\subsection{Analytical Methods}

Inductively coupled plasma mass spectrometry (X-Series 2 Q-ICP-MS, Thermo Fisher Scientific, Waltham, MA, USA) was used to measure the concentration of Cd(II) before and after the experiments.

\section{Results and Discussion}

\subsection{SEM and EDS Analysis}

Figure 3 shows the SEM images of the prepared membranes with various $\mathrm{Al}_{2} \mathrm{O}_{3}$ contents. The particles are well dispersed at low $\mathrm{Al}_{2} \mathrm{O}_{3}$ loadings, whereas the particles tend to agglomerate at higher $\mathrm{Al}_{2} \mathrm{O}_{3}$ loadings (i.e., $20 \%$ or above).

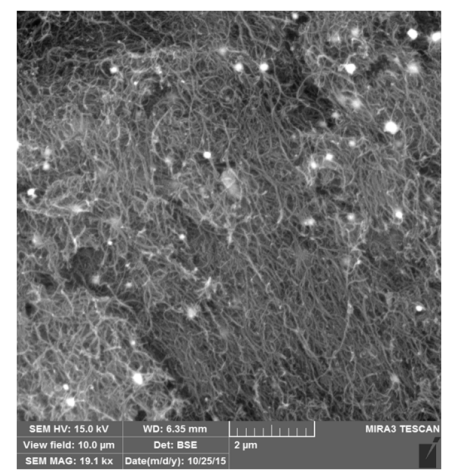

(a)

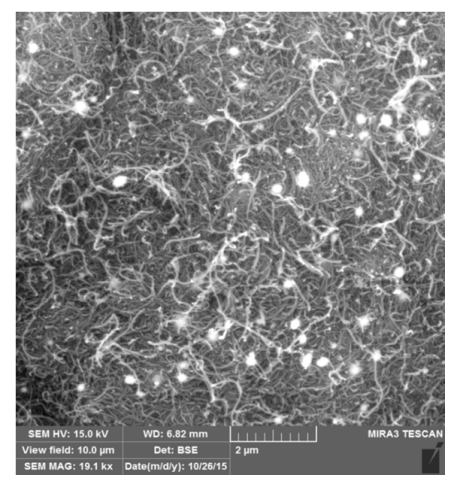

(b)

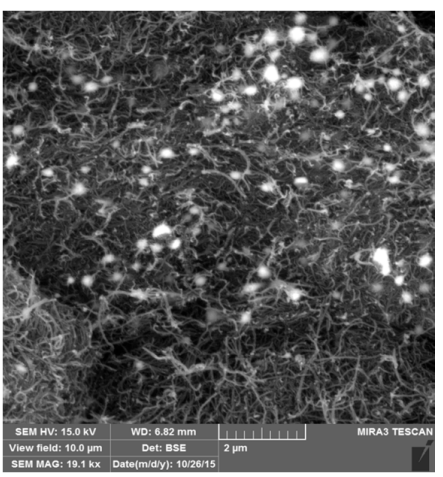

(c)

Figure 3. SEM micrographs of CNT membranes impregnated with (a) $1 \%$; (b) $10 \%$; and (c) $20 \%$ $\mathrm{Al}_{2} \mathrm{O}_{3}$ particles.

\subsection{X-ray Diffraction (XRD)}

Figure 4 displays the XRD patterns of the raw and impregnated CNTs powders. In the XRD pattern of the raw CNTs, the characteristic peaks at $2 \theta=27^{\circ}$ and $44^{\circ}$ correspond to the CNTs. However, the XRD pattern of the impregnated CNTs presents new peaks at $2 \theta=17^{\circ}, 33^{\circ}$, and $40^{\circ}$ in addition to the two apparent peaks associated with the CNTs. These peaks correspond to the $\mathrm{Al}_{2} \mathrm{O}_{3}$ nanoparticles and indicate the successful impregnation of $\mathrm{Al}_{2} \mathrm{O}_{3}$ particles onto the surface of the CNTs. The XRD spectrum shows a minor shift of $\mathrm{CNTs}$ peaks for the $\mathrm{CNT}-\mathrm{Al}_{2} \mathrm{O}_{3}$, possibly due to the residual stresses imposed by the $\mathrm{Al}_{2} \mathrm{O}_{3}$ particles embedded onto the CNTs $[30,31]$.

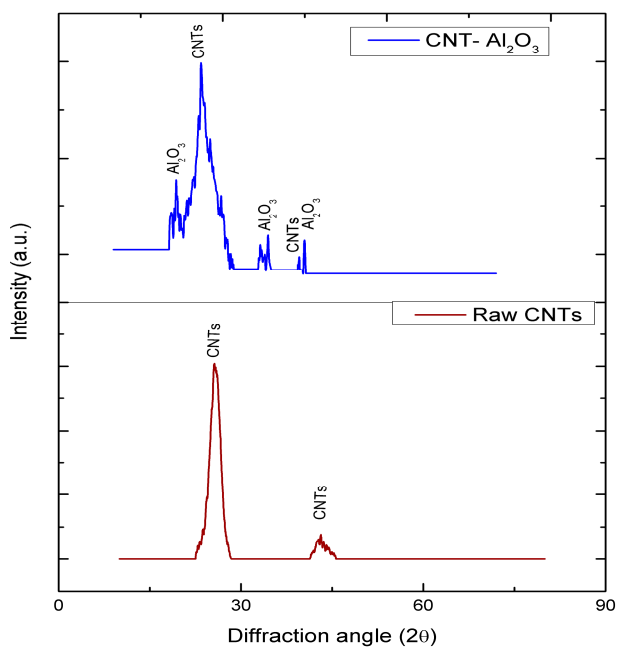

Figure 4. XRD plots of raw and $\mathrm{Al}_{2} \mathrm{O}_{3}$-impregnated CNTs. 


\subsection{Measurement of the Zeta Potential and Point of Zero Electric Charge $\left(\mathrm{pH}_{P Z \mathrm{C}}\right)$}

The zeta potentials of $\mathrm{CNT}-10 \% \mathrm{Al}_{2} \mathrm{O}_{3}$ in distilled water were determined in a $\mathrm{pH}$ range of 2.0-10. As displayed in Figure 5, the surface charge of the membrane surface is positive at $\mathrm{pH}<6.5$ and negative at $\mathrm{pH}>6.5$. The zero electric charge $\left(\mathrm{pH}_{\mathrm{PZC}}\right)$ value of the membrane was noted at 6.5 . The membrane is expected to have a relatively higher removal of $\mathrm{Cd}(\mathrm{II})$ ions at $\mathrm{pH} 7$, as discussed in Section 3.6, because of the electrostatic interactions between the negatively charged membrane surface and cationic $\mathrm{Cd}(\mathrm{II})$ ions.

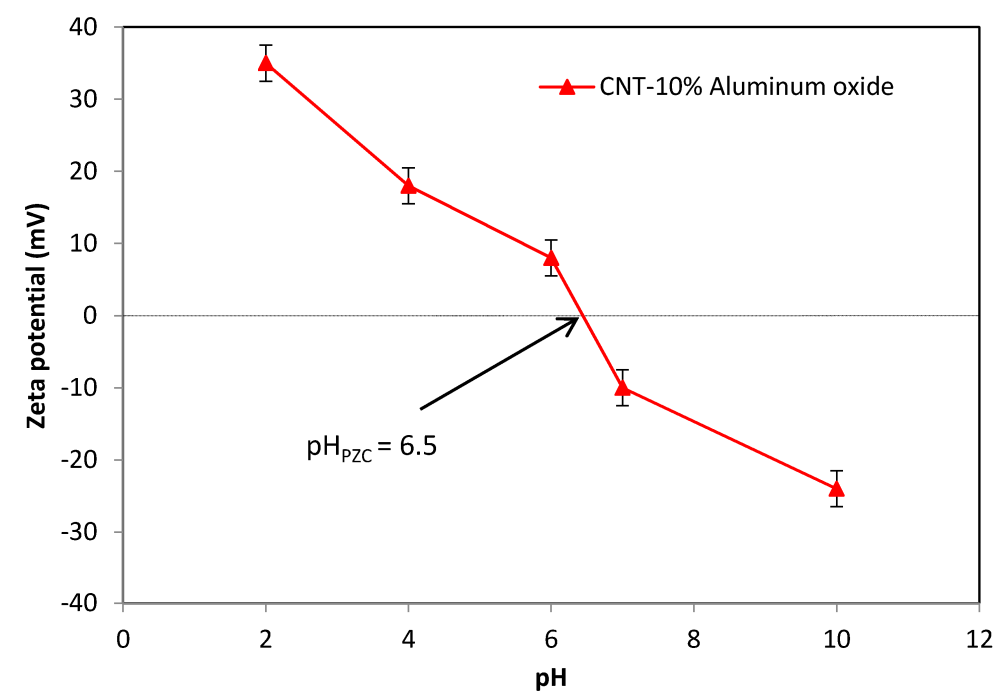

Figure 5. Variation of the zeta potential values with $\mathrm{pH}$ for the $\mathrm{CNT}-\mathrm{Al}_{2} \mathrm{O}_{3}$ membrane.

\subsection{Membrane Characterization}

\subsubsection{Porosity Measurement}

The dry-wet method was used to determine the porosity of the membranes. Figure 6 displays the porosity versus $\mathrm{Al}_{2} \mathrm{O}_{3}$ loading for loadings of 1 to $20 \%$. Considering the standard deviation reported for the measured porosity values, the variation in porosity with $\mathrm{Al}_{2} \mathrm{O}_{3}$ content is rather minor, implying that the $\mathrm{Al}_{2} \mathrm{O}_{3}$ loading does not have a significant effect on the membrane porosity.

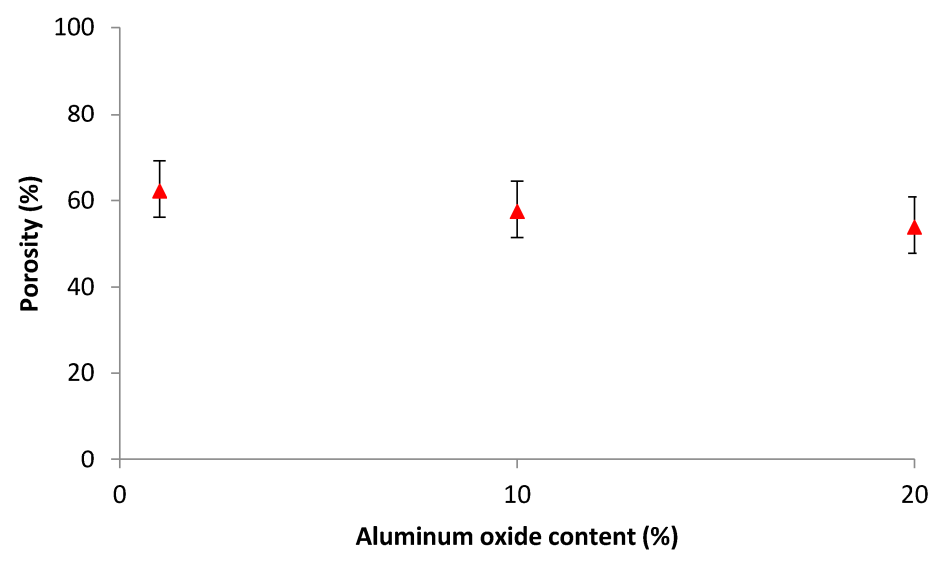

Figure 6. Porosity of the $\mathrm{Al}_{2} \mathrm{O}_{3}$-impregnated CNT membranes. 


\subsubsection{Contact Angle Measurement}

Contact angle measurement is an index of the hydrophobicity/hydrophilicity of the membrane surface. As shown in Figure 7, the contact angle of the membrane decreased with increasing $\mathrm{Al}_{2} \mathrm{O}_{3}$ content. In other words, the hydrophilicity of the membrane increases with increasing $\mathrm{Al}_{2} \mathrm{O}_{3}$ loading. The decrease in contact angle with increase in $\mathrm{Al}_{2} \mathrm{O}_{3}$ loading might be due to change in membrane pore size due to agglomeration at higher $\mathrm{Al}_{2} \mathrm{O}_{3}$ loading. This agglomeration leads to enhanced water flux (as shown in Figure 8), and hence, the contact angle value is decreased. This hydrophilic nature of the membrane is primarily responsible for the enhanced flux through the membrane [28,29].

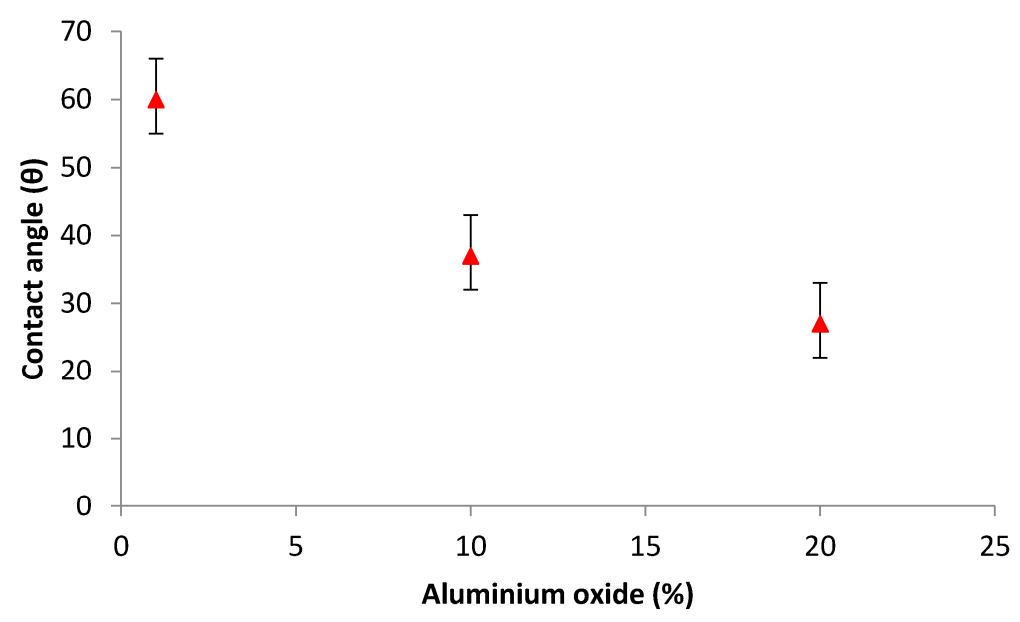

Figure 7. Contact angle of the membrane versus $\mathrm{Al}_{2} \mathrm{O}_{3}$ content.

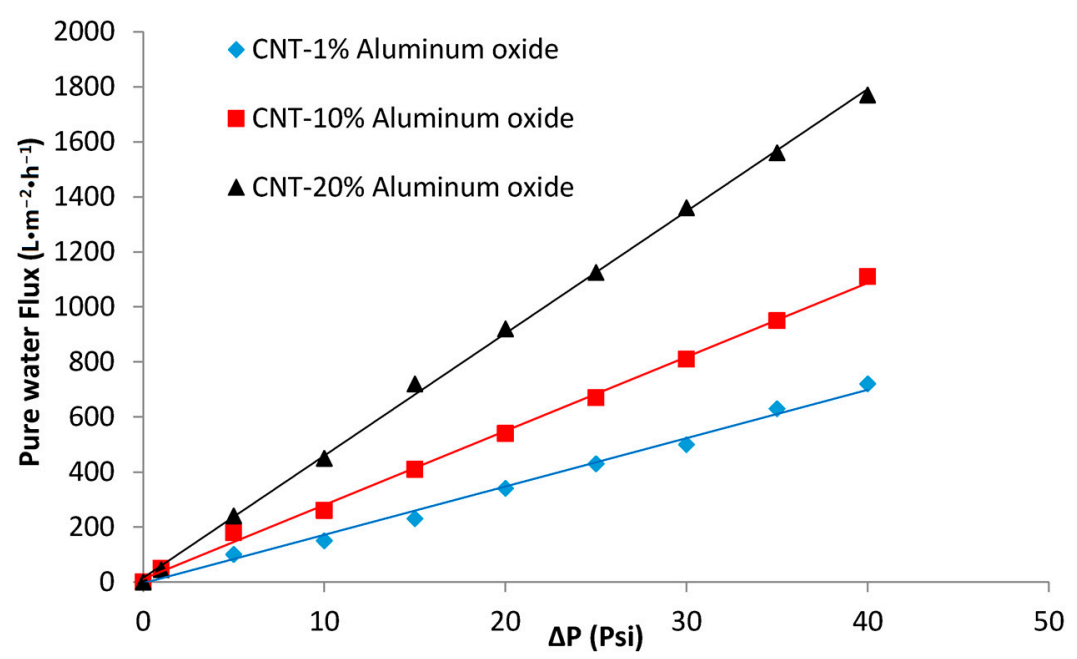

Figure 8. Effect of transmembrane pressure difference on the water flux of the $\mathrm{CNT}-\mathrm{Al}_{2} \mathrm{O}_{3}$ membranes.

\subsection{Water Flux Measurements: Effect of Transmembrane Pressure Difference and Aluminum Oxide Loading}

The effects of transmembrane pressure difference, aluminum oxide loading, and time, on the water flux through the membranes, were studied, as shown in Figure 8. The transmembrane pressure difference was varied from 1 to 40 psi. A nearly linear relationship exists between the pressure and flux for all membranes with different $\mathrm{Al}_{2} \mathrm{O}_{3}$ loadings. The water permeate flux was measured by holding the transmembrane pressure difference constant at 20 psi for $30 \mathrm{~min}$. The permeate flux values for different pressures were obtained using the same procedure. For each reading, the pressure was maintained for $10 \mathrm{~min}$ before noting the readings. 
Figure 8 illustrates that the permeate water flux increased as the $\mathrm{Al}_{2} \mathrm{O}_{3}$ content increased from 1 to $20 \%$. The increased permeate flux for membranes with high $\mathrm{Al}_{2} \mathrm{O}_{3}$ loading can be explained based on two mechanisms. First, the hydrophilic surface of the membrane at high $\mathrm{Al}_{2} \mathrm{O}_{3}$ loading facilitates the transport of water through the membrane (Figure 7). Second, the agglomeration of $\mathrm{Al}_{2} \mathrm{O}_{3}$ particles (Figure 3c) at high loading (20\%) results in the formation of relatively large pores in the membrane, thus contributing to the higher permeate flux.

\subsection{Cadmium Removal}

The Cd(II) ion removal studies were performed in the flow loop system, as shown in Figure 2. The cadmium solution was passed through the $\mathrm{CNT}-\mathrm{Al}_{2} \mathrm{O}_{3}$ membrane. $\mathrm{Cd}(\mathrm{II})$ ions are retained in the feed side while purified water permeates the membrane. The cadmium removal $(\mathrm{R})$ can be determined using the following equation:

$$
R=1-C_{p} / C_{f}
$$

where $C_{p}$ and $C_{f}$ are the concentrations of the solute in the permeate and feed, respectively.

\subsubsection{Effect of Feed $\mathrm{pH}$}

Solution $\mathrm{pH}$ is an important parameter that determines the removal of toxic metal by carbon-based materials. The $\mathrm{Cd}(\mathrm{II})$ removal experiments were performed for the membrane with $10 \% \mathrm{Al}_{2} \mathrm{O}_{3}$ loading in the $\mathrm{pH}$ range of 3-10 (experimental set 1). The results of the analysis are shown in Figure 9.

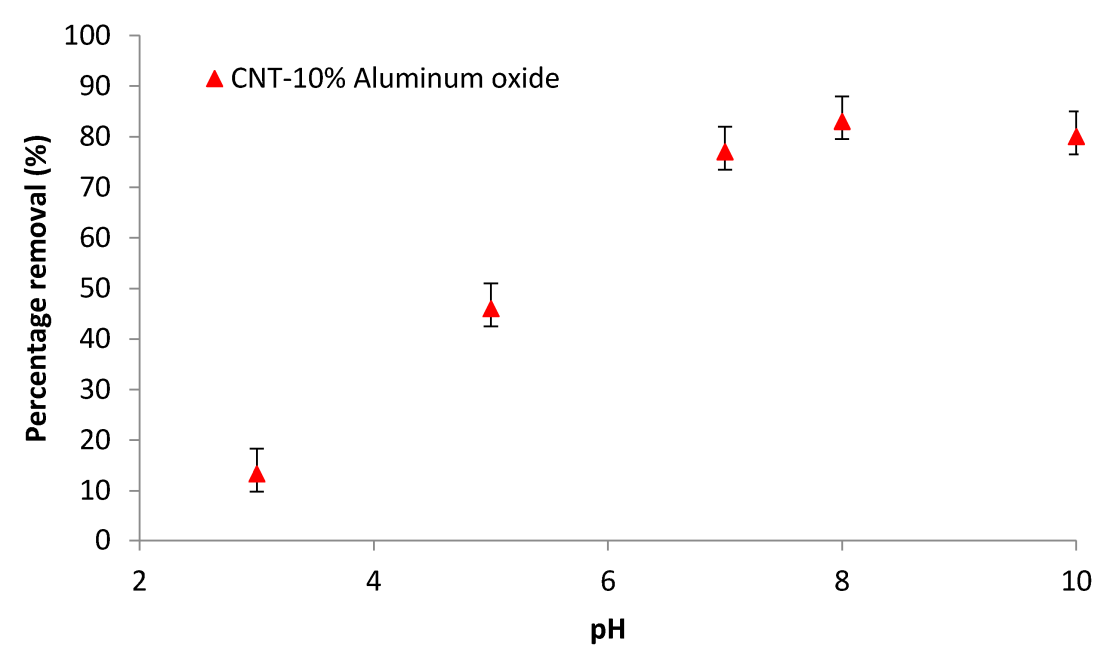

Figure 9. Effect of $\mathrm{pH}$ on the percentage removal of $\mathrm{Cd}(\mathrm{II})$ ions by $\mathrm{CNT}-10 \% \mathrm{Al}_{2} \mathrm{O}_{3}$ membrane (initial concentration $=1 \mathrm{ppm}$, time $=3 \mathrm{~h}$ ).

Cadmium species are present in deionized (DI) water in the form of $\mathrm{Cd}^{2+}, \mathrm{Cd}(\mathrm{OH})^{+}$, and $\mathrm{Cd}(\mathrm{OH})_{2(\mathrm{~s})}[32,33]$. At $\mathrm{pH}<8$, the dominant cadmium species is $\mathrm{Cd}^{2+}$ in the form of complex $\left[\mathrm{Cd}\left(\mathrm{H}_{2} \mathrm{O}\right)_{6}\right]^{2+}$ [34]. The $\mathrm{pH}_{\mathrm{PZC}}$ value for $\mathrm{Al}_{2} \mathrm{O}_{3}$-doped $\mathrm{CNTs}$ is $\mathrm{pH} 6.5$, as shown in Figure 4. This value demonstrates that $\mathrm{Al}_{2} \mathrm{O}_{3}$ is basic in DI water [27]. At $\mathrm{pH}<\mathrm{pH}_{\mathrm{PZC}}$, the membrane surface is positively charged, and repulsion exists between the $\mathrm{Cd}$ (II) ions and surface, causing a low removal rate for $\mathrm{Cd}$ (II) ions. In addition, competition between $\mathrm{H}^{+}$and $\mathrm{Cd}^{2+}$ ions for the active sites decreases the $\mathrm{Cd}(\mathrm{II})$ ions adsorption rate. At $\mathrm{pH}>\mathrm{pH}_{\mathrm{PZC}}$, the surface of the membrane becomes more negatively charged, and thus, additional $\mathrm{Cd}(\mathrm{II})$ ions are attracted to the surface, due to electrostatic interactions.

A maximum removal of $84 \%$ was observed at $\mathrm{pH} 8$. However, cadmium might have precipitated as $\mathrm{Cd}(\mathrm{OH})_{2}$ at $\mathrm{pH}>8$, as reported elsewhere [35,36], and the removal might be due to both adsorption and precipitation. Therefore, $\mathrm{pH} 7$ was used in all experiments as an optimum value to avoid the precipitation of cadmium ions. Moreover, at $\mathrm{pH}>8$, the concentration of $\mathrm{Cd}(\mathrm{II})$ ions is low, and the 
predominant ions are $\mathrm{HCO}_{3}^{-}$. The repulsion between the negatively charged surface of the membrane at $\mathrm{pH}>\mathrm{pH} \mathrm{PZC}$, and the $\mathrm{HCO}_{3}^{-}$ions, causes a decrease in the removal of cadmium ions. In addition to electrostatic interactions, the van der Waals interactions occurring between the cadmium ions and carbon atoms could also induce the adsorption of cadmium ions $[27,37]$.

\subsubsection{Effect of Time}

To study the effect of time on the removal of Cd(II) ions, the experiments were performed at constant $\mathrm{pH}$ 7, and an initial concentration of $1 \mathrm{ppm}$. The samples were collected every $30 \mathrm{~min}$ and analyzed. The results of the analysis are presented in Figure 10. The percentage removal of Cd(II) increases with time until $2 \mathrm{~h}$ of operation, after which no significant increase in removal was observed. Equilibrium was reached within nearly $2 \mathrm{~h}$ for all membranes. The maximum removal rate of $84 \%$ was achieved with the CNT-10\% $\mathrm{Al}_{2} \mathrm{O}_{3}$ membrane. Membranes with $1 \%$ and $20 \% \mathrm{Al}_{2} \mathrm{O}_{3}$ loadings achieved $\mathrm{Cd}$ (II) removal rates of $80 \%$ and $74 \%$, respectively, under similar conditions.

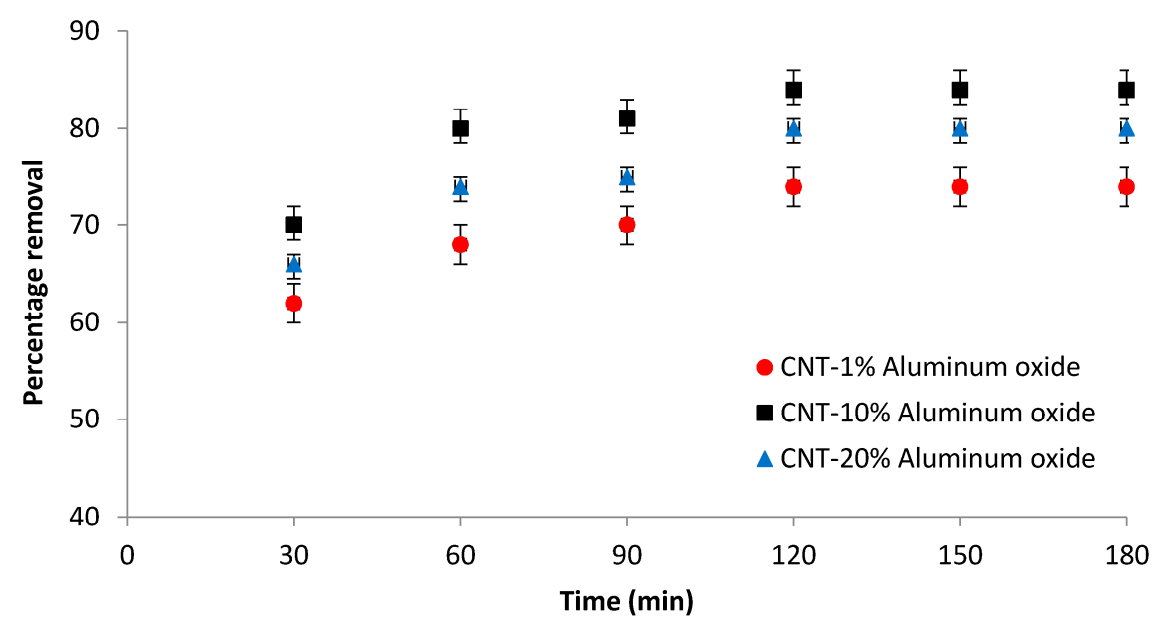

Figure 10. Effect of time on the percentage removal of cadmium ions by the $\mathrm{CNT}-\mathrm{Al}_{2} \mathrm{O}_{3}$ membranes (initial concentration $=1 \mathrm{ppm}, \mathrm{pH}=7$ ).

The relatively higher removal of $\mathrm{Cd}(\mathrm{II})$ ions by the $\mathrm{CNT}-10 \% \mathrm{Al}_{2} \mathrm{O}_{3}$ membrane might be due to the greater number of adsorption sites than the membrane with $1 \% \mathrm{Al}_{2} \mathrm{O}_{3}$ loading. The relatively lower removal of $\mathrm{Cd}$ (II) ions by the membrane with $20 \% \mathrm{Al}_{2} \mathrm{O}_{3}$ loading could be attributed to the agglomeration of $\mathrm{Al}_{2} \mathrm{O}_{3}$ particles at higher loading i.e., $20 \% \mathrm{Al}_{2} \mathrm{O}_{3}$ (as discussed in Section 3.1 (Figure 3c)). This agglomeration might create large pores in the membrane that leads to poor separation of $\mathrm{Cd}(\mathrm{II})$ ions.

\subsubsection{Effect of the Initial Concentration}

Figure 11 presents the effect of the initial concentration of the solution on the percentage removal of $\mathrm{Cd}$ (II) ions. The initial concentration was varied from 0.5 to $10 \mathrm{ppm}$, and the other experimental parameters were $\mathrm{pH} 6$, a contact time of $2 \mathrm{~h}$, and a transmembrane pressure difference of $15 \mathrm{psi}$.

The removal increased slightly from 78 to $84 \%$, as the concentration increased from 0.5 to $1 \mathrm{ppm}$, and remained nearly constant until approximately $5 \mathrm{ppm}$. At an initial concentration of $0.5 \mathrm{ppm}$, the membrane still had available adsorption sites and did not reach saturation; thus, more Cd(II) ions could be adsorbed. The percentage removal remained constant as the concentration was increased from 1 to $5 \mathrm{ppm}$. However, as the concentration increased further beyond $5 \mathrm{ppm}$, the removal decreased slightly, likely because all available adsorption sites were covered by the $\mathrm{Cd}(\mathrm{II})$ ions and the membrane had reached its adsorption equilibrium limit. The membrane was effective in removing a low concentration of $\mathrm{Cd}(\mathrm{II})$ ions. 


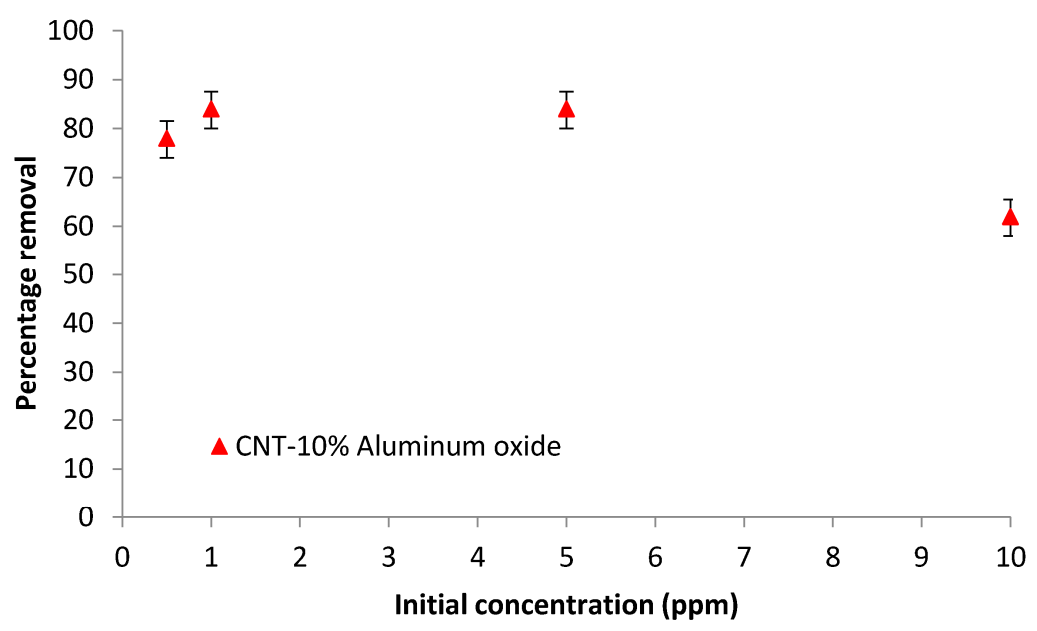

Figure 11. Effect of the initial concentration on the percentage removal of cadmium ions by the $\mathrm{CNT}-10 \% \mathrm{Al}_{2} \mathrm{O}_{3}$ membrane (contact time $=2 \mathrm{~h}, \mathrm{pH}=7$ ).

\subsubsection{Adsorption Isotherms}

The nonlinear forms of the Langmuir and Freundlich adsorption isotherms for the adsorption of cadmium ions on the $\mathrm{CNT}-\mathrm{Al}_{2} \mathrm{O}_{3}$ membrane surface are presented in Figure 12. Representative equations and the results of the analysis are summarized in Table 2.

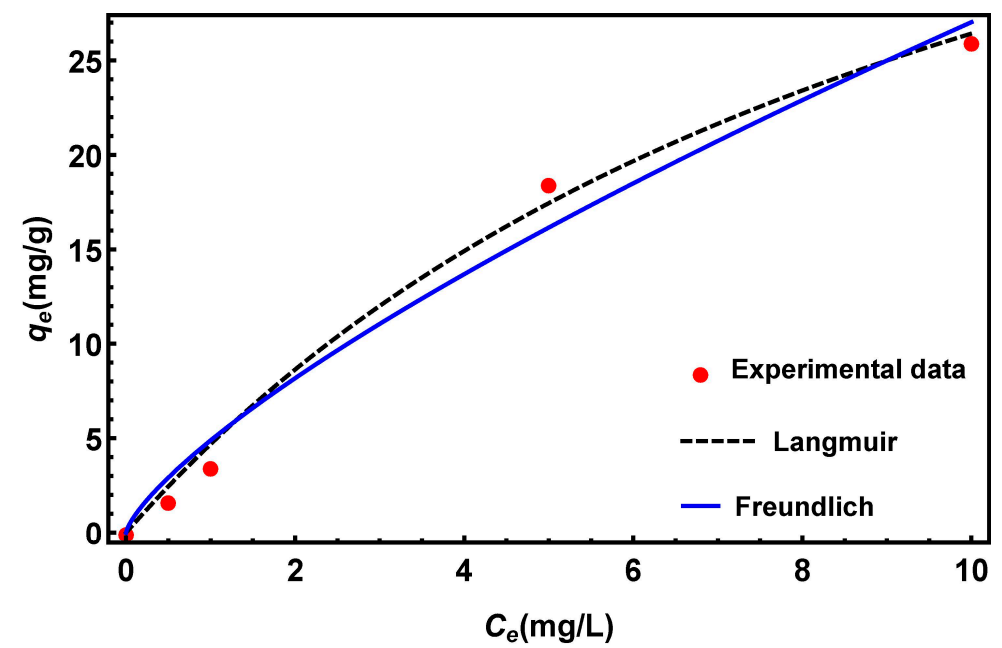

Figure 12. Langmuir and Freundlich adsorption isotherm model fits for the removal of cadmium ions by the $\mathrm{CNT}-10 \% \mathrm{Al}_{2} \mathrm{O}_{3}$ membrane.

Table 2. Langmuir and Freundlich isotherm model parameters for the adsorption of $\mathrm{Cd}(\mathrm{II})$ ions on the CNT- $10 \% \mathrm{Al}_{2} \mathrm{O}_{3}$ membrane.

\begin{tabular}{ccc}
\hline Model & Parameters & CNT-10\% $\mathbf{A l}_{\mathbf{2}} \mathbf{O}_{\mathbf{3}}$ Membrane \\
\hline \multirow{2}{*}{ Langmuir $\left(q_{e}=\frac{q_{m} K_{L C_{e}}}{1+K_{L C_{e}}}\right)$} & $K_{L}(\mathrm{~L} / \mathrm{mg})$ & 0.09 \\
& $q_{m}(\mathrm{mg} / \mathrm{g})$ & 54.42 \\
& $\mathrm{R}^{2}$ & 0.997 \\
\hline \multirow{2}{*}{ Freundlich $\left(q_{e}=K_{F} \cdot C e^{1 / n}\right)$} & $K_{F}(\mathrm{mg} / \mathrm{g}) \cdot(\mathrm{L} / \mathrm{mg})^{1 / n}$ & 4.89 \\
& $\mathrm{~N}$ & 1.35 \\
& $\mathrm{R}^{2}$ & 0.99 \\
\hline
\end{tabular}


In the Langmuir model, $q_{e}(\mathrm{mg} / \mathrm{g})$ represents the concentration of adsorbate on the surface of adsorbent, $C_{e}(\mathrm{mg} / \mathrm{L})$ indicates the concentration of adsorbate in solution when equilibrium was reached, $q_{m}(\mathrm{mg} / \mathrm{g})$ is the maximum adsorption capacity, and $K_{L}$ is the Langmuir adsorption equilibrium constant $(\mathrm{L} / \mathrm{mg})$. In the Freundlich isotherm model, $K_{F}(\mathrm{mg} / \mathrm{g}) \cdot(\mathrm{L} / \mathrm{mg})^{1 / n}$ and $n$ (dimensionless) are Freundlich constants. Mathematica version 10 (Wolfram 2015, Long Hanborough Oxfordshire, UK) was used to plot the isotherm data and determine the values of various parameters.

Both models can describe the experimental data satisfactorily, but the correlation coefficient $\left(\mathrm{R}^{2}\right)$ value for the Langmuir isotherm model is slightly higher than that for the Freundlich isotherm model.

\subsection{Mechanism of Cadmium Ion Removal by the CNT-10\% $\mathrm{Al}_{2} \mathrm{O}_{3}$ Membrane}

The possible mechanism underlying $\mathrm{Cd}(\mathrm{II})$ ion interactions with the $\mathrm{CNT}-\mathrm{Al}_{2} \mathrm{O}_{3}$ membrane is presented in Figure 13. As discussed in Section 3.6.1, the dominant cadmium species in deionized (DI) water is $\mathrm{Cd}(\mathrm{II})$, or $\mathrm{Cd}^{2+}$, in the form of complex $\left[\mathrm{Cd}\left(\mathrm{H}_{2} \mathrm{O}\right)_{6}\right]^{2+}$ at $\mathrm{pH} 7$, used as an optimum value in all experiments. When $\mathrm{pH}<\mathrm{pH}_{\mathrm{PZC}}$, the membrane surface is positively charged, and the low removal of $\mathrm{Cd}$ (II) ions can be attributed to electrostatic repulsions between the $\mathrm{Cd}(\mathrm{II})$ ions and the surface of the $\mathrm{CNT}-\mathrm{Al}_{2} \mathrm{O}_{3}$ membrane. Similarly, the higher removal of $\mathrm{Cd}(\mathrm{II})$ ions at $\mathrm{pH}>\mathrm{pH} \mathrm{HZC}_{\text {might be due to }}$ the strong electrostatic interactions between the negatively charged $\mathrm{CNT}-\mathrm{Al}_{2} \mathrm{O}_{3}$ membrane surface and the cationic $\mathrm{Cd}(\mathrm{II})$ ions [27].

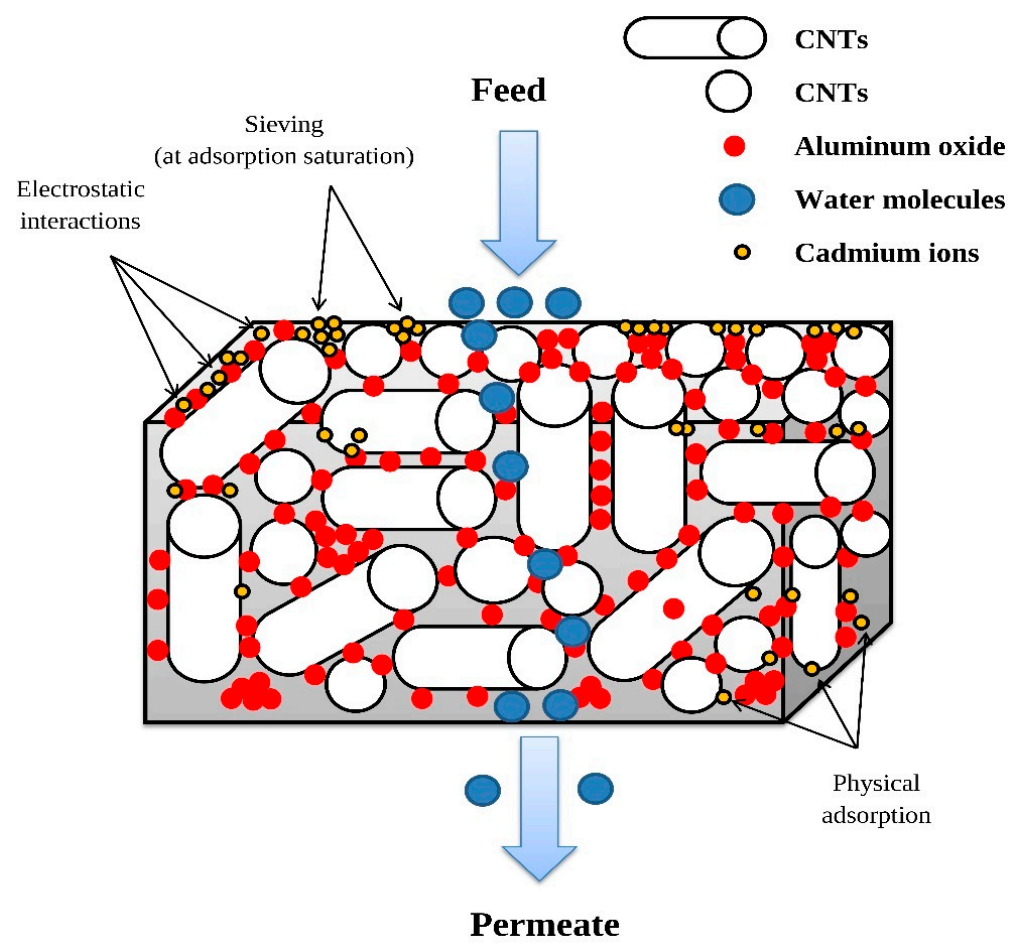

Figure 13. Possible mechanisms of $\mathrm{Cd}(\mathrm{II})$ ion interactions with the $\mathrm{CNT}-\mathrm{Al}_{2} \mathrm{O}_{3}$ membrane.

This observation suggests that electrostatic interaction is the main mechanism involved in the sorption of $\mathrm{Cd}(\mathrm{II})$ ions onto the $\mathrm{CNT}-\mathrm{Al}_{2} \mathrm{O}_{3}$ membrane surface. In addition to electrostatic interaction, $\mathrm{Cd}(\mathrm{II})$ ions might also adsorb on the surface of $\mathrm{CNT}-\mathrm{Al}_{2} \mathrm{O}_{3}$ membrane due to van der Waals interactions (physical adsorption) occurring between $\mathrm{Cd}(\mathrm{II})$ ions and carbon atoms in the $\mathrm{CNT}-\mathrm{Al}_{2} \mathrm{O}_{3}$ composite. At the adsorption saturation of the membrane surface and internal structure, certain pores among the CNTs might be covered by $\mathrm{Cd}$ (II) ions, thus blocking further ions from passing through and acting as sieves (size exclusion). 


\subsection{Comparative Analysis}

The adsorption capacity and removal efficiency of $\mathrm{Cd}(\mathrm{II})$ ions from water for the membrane developed in this study are compared to those of similar studies reported in the literature in Table 3. The estimated maximum Cd(II) adsorption capacity of the CNT- $10 \% \mathrm{Al}_{2} \mathrm{O}_{3}$ membrane is $54.42 \mathrm{mg} / \mathrm{g}$, which is higher than those of related adsorbents (used in batch experiments), such as raw CNTs $(1.661 \mathrm{mg} / \mathrm{g})$ [38], acid-modified CNTs $(4.35 \mathrm{mg} / \mathrm{g})$ [3], ethylenediamine-functionalized multi-walled carbon nanotubes (MWCNTs) $(25.70 \mathrm{mg} / \mathrm{g}$ ) [33] and nano-alumina on single-walled carbon nanotube (SWCNTs) $(2.18 \mathrm{mg} / \mathrm{g})$ [39]. This result suggests that the $\mathrm{CNT}-\mathrm{Al}_{2} \mathrm{O}_{3}$ membrane is effective in removing low concentrations of $\mathrm{Cd}$ (II) ions from water.

Table 3. Comparative analysis of the adsorption capacity and removal efficiency of Cd(II) ion removal.

\begin{tabular}{|c|c|c|c|c|}
\hline Adsorbent & Experimental Conditions & $\begin{array}{l}\text { Percentage } \\
\text { Removal }\end{array}$ & $\begin{array}{c}\text { Adsorption } \\
\text { Capacity (mg/g) }\end{array}$ & Reference \\
\hline As-grown CNTs & $\mathrm{pH} 5.5$, initial concentration $=4 \mathrm{mg} / \mathrm{L}$ & - & 1.1 & [2] \\
\hline $\mathrm{H}_{2} \mathrm{O}_{2}$ oxidized $\mathrm{CNTs}$ & $\mathrm{pH} 5.5$, initial concentration $=4 \mathrm{mg} / \mathrm{L}$ & - & 2.6 & [2] \\
\hline $\mathrm{HNO}_{3}$ oxidized $\mathrm{CNTs}$ & $\mathrm{pH} 5.5$, initial concentration $=4 \mathrm{mg} / \mathrm{L}$ & - & 5.1 & [2] \\
\hline Acid-modified CNTs & $\mathrm{pH} 7$, initial concentration $=1 \mathrm{ppm}$ & 93 & 4.35 & [3] \\
\hline Raw CNTs & $\mathrm{pH} 7$, initial concentration $=1 \mathrm{ppm}$ & 27 & 1.661 & {$[38]$} \\
\hline $\begin{array}{l}\text { Ethylenediamine- } \\
\text { functionalized MWCNTs }\end{array}$ & $\mathrm{pH} 8$, initial concentration $=5 \mathrm{mg} / \mathrm{L}$ & - & 25.70 & [33] \\
\hline SWCNTs & pH 8 & - & 1.97 & [39] \\
\hline $\begin{array}{l}\text { Nano-alumina/ } \\
\text { SWCNTs }\end{array}$ & $\mathrm{pH} 8$ & - & 2.18 & [39] \\
\hline SWCNTs-COOH & $\mathrm{pH} 5$, initial concentration $=20 \mathrm{mg} / \mathrm{L}$ & 69.97 & 55.89 & [40] \\
\hline $\begin{array}{l}\mathrm{CNT}-10 \% \mathrm{Al}_{2} \mathrm{O}_{3} \\
\text { membrane }\end{array}$ & $\begin{array}{c}\mathrm{pH} 7, \text { initial concentration }=1 \mathrm{mg} / \mathrm{L}, \\
\text { contact time }=2 \mathrm{~h}\end{array}$ & 84 & 54.42 & This study \\
\hline
\end{tabular}

\section{Conclusions}

A novel approach was developed to synthesize an aluminum oxide-impregnated CNT membrane. No binder was used in the membrane synthesis; instead, aluminum oxide particles served as a binder to hold the 3D CNT network together. The membrane surface demonstrated extreme hydrophilic behavior and yielded a high water flux. The membrane was able to remove low concentrations of $\mathrm{Cd}(\mathrm{II})$ ions from aqueous solution. The removal was affected by the aluminum oxide loading, initial cadmium solution concentration, $\mathrm{pH}$, and time. The maximum $\mathrm{Cd}(\mathrm{II})$ removal of $84 \%$ was obtained at $\mathrm{pH} 7$ and an initial concentration of 1 ppm using the CNT membrane with $10 \% \mathrm{Al}_{2} \mathrm{O}_{3}$ loading and $2 \mathrm{~h}$ of operation. Membranes with $1 \%$ and $20 \% \mathrm{Al}_{2} \mathrm{O}_{3}$ loadings were able to remove $80 \%$ and $74 \%$ of $\mathrm{Cd}(\mathrm{II})$ ions, respectively, under similar experimental conditions. These results suggest that the $\mathrm{CNT}-\mathrm{Al}_{2} \mathrm{O}_{3}$ membrane can be effectively used in a continuous filtration system for the removal of $\mathrm{Cd}$ (II) ions.

Acknowledgments: The authors acknowledge support from King Abdulaziz City for Science and Technology (KACST) through the Science \& Technology Unit at King Fahd University of Petroleum \& Minerals (KFUPM) and funding of this work through Project No: 13-ADV161-04 as part of the National Science Technology and Innovation Plan (NSTIP).

Author Contributions: Ihsanullah, Muataz Ali Atieh and Tahar Laoui conceived and designed the experiments; Ihsanullah performed the experiments; Ihsanullah and Tahar Laoui analysed the data; Faheemuddin Patel contributed reagents/materials/analysis tools; Ihsanullah, Tahar Laoui and Majeda Khraisheh wrote the paper.

Conflicts of Interest: The authors declare no conflict of interest.

\section{References}

1. World Health Organization. International Standards for Drinking Water; WHO: Geneva, Switzerland, 2008. 
2. Li, Y.; Wang, S.; Luan, Z.; Ding, J.; Xu, C. Adsorption of cadmium(II) from aqueous solution by surface oxidized carbon nanotubes. Carbon 2003, 41, 1057-1062. [CrossRef]

3. Ihsanullah; Al-Khaldi, F.A.; Abusharkh, B.; Khaled, M.; Atieh, M.A.; Nasser, M.S.; Laoui, T.; Saleh, T.A.; Agarwal, S.; Tyagi, I.; et al. Adsorptive removal of cadmium(II) ions from liquid phase using acid modified carbon-based adsorbents. J. Mol. Liq. 2015, 204, 255-263. [CrossRef]

4. Wang, F.Y.; Wang, H.; Ma, J.W. Adsorption of cadmium(II) ions from aqueous solution by a new low-cost adsorbent-Bamboo charcoal. J. Hazard. Mater. 2010, 177, 300-306. [CrossRef] [PubMed]

5. Li, Q.; Wu, S.; Liu, G.; Liao, X.; Deng, X.; Sun, D.; Hu, Y.; Huang, Y. Simultaneous biosorption of cadmium(II) and lead(II) ions by pretreated biomass of phanerochaete chrysosporium. Sep. Purif. Technol. 2004, 34, 135-142. [CrossRef]

6. Ihsanullah; Abbas, A.; Al-Amer, A.M.; Laoui, T.; Al-Marri, M.J.; Nasser, M.S.; Khraisheh, M.; Atieh, M.A. Heavy metal removal from aqueous solution by advanced carbon nanotubes: Critical review of adsorption applications. Sep. Purif. Technol. 2016, 157, 141-161. [CrossRef]

7. Asmaly, H.A.; Abussaud, B.; Ihsanullah; Saleh, T.A.; Gupta, V.K.; Atieh, M.A. Ferric oxide nanoparticles decorated carbon nanotubes and carbon nanofibers: From synthesis to enhanced removal of phenol. J. Saudi Chem. Soc. 2015, 19, 511-520. [CrossRef]

8. Asmaly, H.A.; Abussaud, B.; Ihsanullah; Saleh, T.A.; Bukhari, A.A.; Laoui, T.; Shemsi, A.M.; Gupta, V.K.; Atieh, M.A. Evaluation of micro- and nano-carbon-based adsorbents for the removal of phenol from aqueous solutions. Toxicol. Environ. Chem. 2015, 97, 1164-1179. [CrossRef]

9. Abbas, A.; Abussaud, B.A.; Al-baghli, N.A.H.; Khraisheh, M.; Atieh, M.A. Benzene removal by iron oxide nanoparticles decorated carbon nanotubes. J. Nanomater. 2016, 2016, 5654129. [CrossRef]

10. Abbas, A.; Abussaud, B.A.; Ihsanullah; Al-baghli, N.A.H.; Redhwi, H.H. Adsorption of Toluene and Paraxylene from aqueous solution using pure and iron oxide impregnated carbon nanotubes: Kinetics and isotherms study. Bioinorg. Chem. Appl. 2017, 2017, 2853925. [CrossRef] [PubMed]

11. Ho, K.C.; Teow, Y.H.; Ang, W.L.; Mohammad, A.W. Novel GO/OMWCNTs mixed-matrix membrane with enhanced antifouling property for palm oil mill effluent treatment. Sep. Purif. Technol. 2017, 177, 337-349. [CrossRef]

12. Li, S.; Liao, G.; Liu, Z.; Pan, Y.; Wu, Q.; Weng, Y.; Zhang, X.; Yang, Z.; Tsui, O.K.C. Enhanced water flux in vertically aligned carbon nanotube arrays and polyethersulfone composite membranes. J. Mater. Chem. A 2014, 2, 12171-12176. [CrossRef]

13. Majumder, M.; Chopra, N.; Andrews, R.; Hinds, B.J. Nanoscale hydrodynamics: Enhanced flow in carbon nanotubes. Nature 2005, 438, 44. [CrossRef] [PubMed]

14. Holt, J.K.; Park, H.G.; Wang, Y.; Stadermann, M.; Artyukhin, A.B.; Grigoropoulos, C.P.; Noy, A.; Bakajin, O. Fast mass transport through sub-2-nanometer carbon nanotubes. Science 2006, 312, 1034-1037. [CrossRef] [PubMed]

15. Srivastava, A.; Srivastava, O.N.; Talapatra, S.; Vajtai, R.; Ajayan, P.M. Carbon nanotube filters. Nat. Mater. 2004, 3, 610-614. [CrossRef] [PubMed]

16. Majeed, S.; Fierro, D.; Buhr, K.; Wind, J.; Du, B.; Boschetti-de-Fierro, A.; Abetz, V. Multi-walled carbon nanotubes (MWCNTs) mixed polyacrylonitrile (PAN) ultrafiltration membranes. J. Membr. Sci. 2012, 403-404, 101-109. [CrossRef]

17. Deb, A.K.S.; Dwivedi, V.; Dasgupta, K.; Ali, S.M.; Shenoy, K.T. Novel amidoamine functionalized multi-walled carbon nanotubes for removal of mercury(II) ions from wastewater: Combined Experimental and density functional theoretical approach. Chem. Eng. J. 2017, 313, 899-911.

18. Lee, J.; Ye, Y.; Ward, A.J.; Zhou, C.; Chen, V.; Andrew, I.; Lee, S.; Liu, Z.; Chae, S.; Shi, J. High flux and high selectivity carbon nanotube composite membrane for natural organic matter removal. Sep. Purif. Technol. 2016, 163, 109-119. [CrossRef]

19. Zarrabi, H.; Ehsan, M.; Vatanpour, V.; Shockravi, A.; Safarpour, M. Improvement in desalination performance of thin film nanocomposite nano filtration membrane using amine-functionalized multiwalled carbon nanotube. Desalination 2016, 394, 83-90. [CrossRef]

20. Hinds, B.J.; Chopra, N.; Rantell, T.; Andrews, R.; Gavalas, V.; Bachas, L.G. Aligned multiwalled carbon nanotube membranes. Science 2004, 303, 62-65. [CrossRef] [PubMed]

21. Andrews, R.; Jacques, D.; Rao, A.M.; Derbyshire, F.; Qian, D.; Fan, X.; Dickey, E.C.; Chen, J. Continuous production of aligned carbon nanotubes: A step closer to commercial realization. Chem. Phys. Lett. 1999, 303, 467-474. [CrossRef] 
22. Pham, G.T.; Park, Y.-B.; Wang, S.; Liang, Z.; Wang, B.; Zhang, C.; Funchess, P.; Kramer, L. Mechanical and electrical properties of polycarbonate nanotube buckypaper composite sheets. Nanotechnology 2008, 19, 325705. [CrossRef] [PubMed]

23. Dumée, L.F.; Sears, K.; Schütz, J.; Finn, N.; Huynh, C.; Hawkins, S.; Duke, M.; Gray, S. Characterization and evaluation of carbon nanotube Bucky-Paper membranes for direct contact membrane distillation. J. Membr. Sci. 2010, 351, 36-43. [CrossRef]

24. Cooper, S.M.; Chuang, H.F.; Cinke, M.; Cruden, B.A.; Meyyappan, M. Gas permeability of a buckypaper membrane. Nano Lett. 2003, 3, 189-192. [CrossRef]

25. Wang, C.; Li, M.; Pan, S.; Li, H. Well-aligned carbon nanotube array membrane synthesized in porous alumina template by chemical vapor deposition. Chin. Sci. Bull. 2000, 45, 1373-1376. [CrossRef]

26. Tofighy, M.A.; Shirazi, Y.; Mohammadi, T.; Pak, A. Salty water desalination using carbon nanotubes membrane. Chem. Eng. J. 2011, 168, 1064-1072. [CrossRef]

27. Liang, J.; Liu, J.; Yuan, X.; Dong, H.; Zeng, G.; Wu, H.; Wang, H.; Liu, J.; Hua, S.; Zhang, S.; et al. Facile synthesis of alumina-decorated multi-walled carbon nanotubes for simultaneous adsorption of cadmium ion and trichloroethylene. Chem. Eng. J. 2015, 273, 101-110. [CrossRef]

28. Ihsanullah; Al Amer, A.M.; Laoui, T.; Abbas, A.; Al-aqeeli, N.; Patel, F.; Khraisheh, M.; Ali, M.; Hilal, N. Fabrication and antifouling behaviour of a carbon nanotube membrane. Mater. Des. 2016, 89, 549-558. [CrossRef]

29. Ihsanullah; Laoui, T.; Al-Amer, A.M.; Khalil, A.B.; Abbas, A.; Khraisheh, M.; Atieh, M.A. Novel anti-microbial membrane for desalination pretreatment: A silver nanoparticle-doped carbon nanotube membrane. Desalination 2015, 376, 82-91. [CrossRef]

30. Wei, T.; Fan, Z.; Luo, G.; Wei, G. A new structure for multi-walled carbon nanotubes reinforced alumina nanocomposite with high strength and toughness. Mater. Lett. 2008, 62, 641-644. [CrossRef]

31. Wang, K.; Wang, Y.; Fan, Z.; Yan, J.; Wei, T. Preparation of graphene nanosheet/alumina composites by spark plasma sintering. Mater. Res. Bull. 2011, 46, 315-318. [CrossRef]

32. Leyva-Ramos, R.; Rangel-Mendez, J.R.; Mendoza-Barron, J.; Fuentes-Rubio, L.; Guerrero-Coronado, R.M. Adsorption of cadmium(II) from aqueous solution onto activated carbon. Water Sci. Technol. 1997, 35, 205-211. [CrossRef]

33. Vukovic, G.D.; Marinkovic, A.D.; Coli, M.; Risti, M.Đ.; Aleksić, R.; Perić-Grujić, A.A.; Uskoković, P.S. Removal of cadmium from aqueous solutions by oxidized and ethylenediamine-functionalized multi-walled carbon nanotubes. Chem. Eng. J. 2010, 157, 238-248. [CrossRef]

34. Ozutsumi, K.; Takamuku, T.; Shin-ichi, I.; Ohtaki, H. An X-ray diffraction study on the structure of solvated cadmium(II) ion and tetrathiocyanatocadmate(II) complex in N,N-dimethylformamide. Bull. Chem. Soc. Jpn. 1989, 62, 1875-1879. [CrossRef]

35. Ahn, C.K.; Kim, Y.M.; Woo, S.H.; Park, J.M. Removal of cadmium using acid-treated activated carbon in the presence of nonionic and/or anionic surfactants. Hydrometallurgy 2009, 99, 209-213. [CrossRef]

36. Ahn, C.K.; Park, D.; Woo, S.H.; Park, J.M. Removal of cationic heavy metal from aqueous solution by activated carbon impregnated with anionic surfactants. J. Hazard. Mater. 2009, 164, 1130-1136. [CrossRef] [PubMed]

37. Gao, Z.; Bandosz, T.J.; Zhao, Z.; Han, M.; Qiu, J. Investigation of factors affecting adsorption of transition metals on oxidized carbon nanotubes. J. Hazard. Mater. 2009, 167, 357-365. [CrossRef] [PubMed]

38. Al-Khaldi, F.A.; Abu-Sharkh, B.; Abulkibash, A.M.; Atieh, M.A. Cadmium removal by activated carbon, carbon nanotubes, carbon nanofibers, and carbon fly ash: A comparative study. Desalin. Water Treat. 2015, 53, 1417-1429. [CrossRef]

39. Kalfa, O.M.; Yalçinkaya, Ö.; Türker, A.R. Synthesis and characterization of nano-scale alumina on single walled carbon nanotube. Inorg. Mater. 2009, 45, 988-992. [CrossRef]

40. Moradi, O. The removal of ions by functionalized carbon nanotube: Equilibrium, isotherms and thermodynamic studies. Chem. Biochem. Eng. Q. 2011, 25, 229-240.

(C) 2017 by the authors. Licensee MDPI, Basel, Switzerland. This article is an open access article distributed under the terms and conditions of the Creative Commons Attribution (CC BY) license (http:/ / creativecommons.org/licenses/by/4.0/). 